\title{
Tradition, reception og fortolkning
}

Dette sidste nummer afårgang2017 er præget afdehistorisk orienterede teologiske discipliner, eksegesen og kirke- og dogmehistorien. Den første artikel af Melissa Sayyad Bach og Jesper Høgenhaven handler om Koranens betegnelse for Muhammad "profeternes segl". I senere islamisk tradition kendes en legende om, at Muhammad siden sin barndom bar et fysisk kendetegn, "profetiens segl”, på sin ryg. En kristen syrisk munk skal som den første have opdaget tegnet. Bach og Høgenhaven forsøger at spore oprindelsen til seglbilledet. Tertullian kalder Kristus for "alle profeters segl" med afsæt i Dan 9,24. Artiklen undersøger særligt den syriske kirkefader Afrahat som en mulig forbindelsesled mellem den kristologiske brug af seglbilledet og Koranen, og påviser et slægtskab imellem Afrahats tolkning af GT og Koranens syn på de tidligere profetiske åbenbaringer.

Den anden artikel, skrevet af Andreas Riis Damgaard, drejer sig om to markante receptioner af Salme 24. Det er dels den norske ekseget Sigmund Mowinckels indflydelsesrige tese om salmens kultiske brug som led i Jahves tronbestigelsesfest, dels salmens reception i Georg Freidrich Händels oratorium Messias. Damgaard påviser den karakter af vekselsang, som er indbygget i Salme $24 \mathrm{~s}$ tekst, og analyserer Mowinckels kultisk orienterede tolkning af salmen i en bredere forskningshistorisk kontekst. I Händels Messias indgår Salme 24 i kor 30 (Lift up Ye Heads), som befinder sig på et centralt punkt (der samtidig er et vendepunkt) i værkets anden del. Damgaard viser, hvordan bibelfortolkningen i Messias overordnet er bestemt af et klassisk typologisk perspektiv, og diskuterer de tydelige lighedspunkter imellem de to receptioner af salmen.

Den tredje artikel af Peter Olsen er en studie udlægninger af Guds forudbestemmelse til frelse og fortabelse og viljens frihed og ufrihed i ældre luthersk tradition. Problemet om, hvordan Gud kan have forudbestemt mennesker til frelse i forhold til spørgsmålet om menneskets vilje optog såvel Luther som Melanchton; og diskussionen fortætter ind i den lutherske orthodoksi. I 1800-tallets slutning kom det til en fornyet debat om emnet blandt lutherske kirker i USA.

Nummeret afsluttes med en artikel af Troels Engberg-Pedersen, som leverer et gensvar til Jesper Tang Nielsens anmeldelse af EngbergPedersens bog om Johannesevangeliet (John and Philosophy, 2017). Artiklen rejser det principielle spørgsmål om den nytestamentlige eksegese som videnskab, og plæderer for videnskabens særlige opgave at udvide, forøge og forbedre forståelsen af de antikke tekster ved at gå ud over traditionelle fortolkninger. 